\title{
Analisis of Digital Information Media for Education in the Purwodadi Botanic Garden Using Analytical Hierarchy Process
}

\author{
Rachmawan Adi Laksono ${ }^{1}$ and Hari Ginardi R.V. ${ }^{2}$ \\ ${ }^{1}$ Department of Technology Management, Institut Teknologi Sepuluh Nopember, Surabaya, Indonesia \\ ${ }^{2}$ Department of Information Technology, Institut Teknologi Sepuluh Nopember, Surabaya, Indonesia \\ e-mail: rachmawanadi@gmail.com
}

\begin{abstract}
Purwodadi Botanical Garden is an ex-situ plant conservation institution. According to Presidential Regulation No. 93 of 2011 the Botanical Gardens have the duties of conservation, research, education, environmental services. Wisata Flora is an educational package conducted by Purwodadi Botanical Garden, the activity depends on the Wisata flora tour guide and the information boards in the garden. The availability of tour guides is still limited, and the information boards supporting Wisata Flora are also limited. This was obtained from interviews with visitors who use the Purwodadi Botanical Gardens education service. Therefore, we need a breakthrough in the way of delivering information to support flora tourism activities by utilizing digital technology. Digitalization is an environmentally friendly alternative compared to through the addition of information in physical form. Some of the technologies that exist today can be used as an alternative delivery of information to visitors independently, namely Quick Response (QR) Codes, RadioFrequency Identification (RFID), and Location Based Service (LBS). Of the three alternatives required a priority of application in accordance with the needs and management capabilities of Purwodadi Botanical Gardens. The research will be conducted using the quesioner and interview method with the management of Purwodadi Botanical Gardens and analyzed using the Analytical Hierarchy Process method. The results of the analysis are expected to be valuable input for the management of Purwodadi Botanical Gardens.
\end{abstract}

Keywords-Flora Education Tourism, Alternative Technology, Analytical Hierarcy Process.

\section{INTRODUCTION}

K EBUN Raya is an institution that worked specialized on ex situ plant conservation. In Indonesia, the Botanical Gardens are managed by the Indonesian Institute of Sciences (LIPI) and also several local governments. The regulation of botanical gardens in Indonesia is regulated in Presidential Regulation No.93 of 2011. According to the regulations, the concerning obligations of botanical gardens i.e. conservation, research, education, and environmental services [1]

Plant Conservation Institution (BKT) Purwodadi Botanic Garden, is one of four botanical gardens managed by LIPI [2]. Purwodadi Botanic Garden has a long history in its establishment. The history of the Purwodadi Botanic Garden began in 1941. L.G.M. Baas Becking is the initiator of the establishment of dry climate hortus Purwodadi or currently known as Purwodadi Botanic Garden. On the beginning of the establishment, Purwodadi Botanic Garden was a branch of the

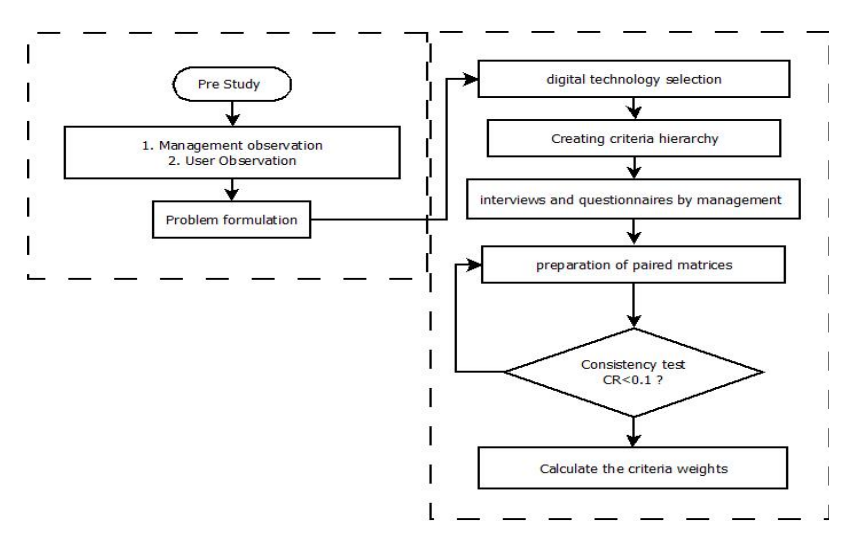

Figure 1. Research Methodology

Bogor Botanic Gardens who had a special task to conserve plants from the dry lowlands area in Indonesia [3].

In the Presidential Regulation No.93 of 2011 mentioned one of the tasks of the botanical garden, which is education. Purwodadi Botanic Gardens carrying out these functions by packaging the activities called flora tourism education. Flora tourism aims is intend to complement the education about plants in schools. In this activity the participants will be guided about the introduction of the botanical garden, the scientific name of the plant, the name of the area of the plant, the character of the plant, and the usefulness of the plant in life. Recently, some of the information media available at Purwodadi Botanic Garden are orientation maps located near the entrance gate, Purwodadi Botanic Garden information services boards located on the main road, nameboards located in almost every collection, and interpretation boards that located in each block of the collection. In addition, there is a Botanical Garden Information Building that provided with several displays describing the activities carried out by Purwodadi Botanic Garden. It is expected that with this information media may support environmental education activities which has been run so far [4].

However, the current implementation still got some obstacles. During the interviews process with the activity management and from flora tourism users the problems encountered can described. Some weaknesses of the implementation of flora tourism are limited number of guide, that makes the number of scouting groups become too large, and also the lack and limited number of interpretation boards and species nameplates, that might support the flora education tourism. 


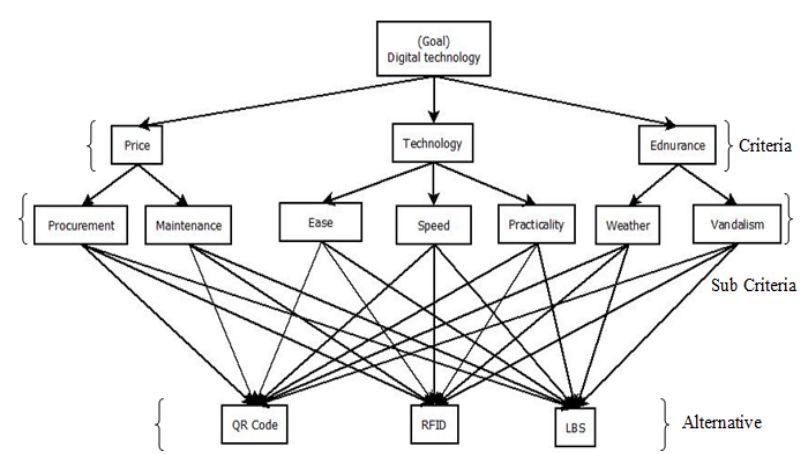

Figure 2. Hierarchy of Digital Media Flora Education Tourism.

The problems mentioned above are need to solve. An innovation in conveying information to visitors need to create as a part of solution. This innovation will also be a support system of flora tourism activities at Purwodadi Botanic Garden. One method that might be used is by using digital technology that can be accessed by visitors independently. Information digitalization is a way to change the delivery of information from using material to dematerial [5].

\section{METHOD}

The research methodology that will be carried out in this study is as in Figure 1. In this study, it was carried out in two phases, the first phase was problem identification while the second phase was problem solving using the AHP method. In the first phase, problem identification is done by interviewing the management and users of the Purwodadi Botanic Garden. After the interview can be concluded the problems faced and become research material.

The second phase starts with the selection of digital technology that will be used. The choice of digital technology is based on previous studies on the use of digital technology in education and tourism. Some previous studies,such as, the use of QR Codes in a museum in Chile that can be used by visitors independently [6]. As well as Quick Response (QR) Codes, Radio Frequency Identification (RFID) is also used at the Mpu Tantular State Museum in Buduran, Sidoarjo. The technology is used to provide more information for visitors. In addition to the two technologies in Gunung Kidul district, Location Based System (LBS)-based tourism information technology was also developed. From the three studies, the digital technology that has been used was chosen as an alternative media for flora tourism information at Purwodadi Botanic Garden.

The Purwodadi Botanic Garden management who will be interviewed and fill out a questionnaire i.e,

1. Head of Purwodadi Botanic Garden,

2. Head of Services and Information Section.

3. Head of Plant Exploration and Collection Section.

4. Head of Administration sub-section.

5. Supervisor Registration Data Collection.

6. Supervisor of Botanical Garden Services.

The six officials interviewed and filled out the forms were officials and executors who were responsible and had authority in terms of strategic and flora tourism services at Purwodadi Botanic Garden. The results of the expert questionnaire above will be used as a basis for analysis using the Analytical Hierarchy Process method. The final result will show the best technology choosen by the Purwodadi Botanic Garden management to solve the problem Based on [7], the AHP calculation method can be done in several steps:

\section{A. Drafting a decision hierarchy of problems.}

The making of a hierarchy is the decomposition of problems to achieve the goals set. Arrangement of structural elements is described in a series of rational systems. It can be concluded that the preparation of the hierarchy is to compose the composing structure to achieve the main goal.

\section{B. Compilation of matrices and pair comparisons.}

Element assessment is filling the weight of each criterion based on the importance value. Assessments are conducted in pairs on each hierarchy that has been made. Filling in the value of interests is carried out by experts who have been determined.

\section{Consistency test.}

Consistency testing needs to be done to see the results of the assessment of experts, whether it meets the consistent requirements. Basically the consistency test can be assumed as if $\mathrm{A}$ is more important than $\mathrm{B}$, then $\mathrm{B}$ is more important than $\mathrm{C}$ then there is no way $\mathrm{C}$ is more important than $\mathrm{A}$. To know that use CI (Consistency Index) compared to RI (Ratio Index) or CR (Consistency Ratio) .

D. Calculation of criteria weights.

Calculation of each paired matrix is performed on each element. From each paired matrix will produce a weight value of each criterion. The results of the assessment can be called the weight of the assessment used to set priorities to be used.

\section{RESULT and DISCUSSION}

\section{A. Hierarchy}

Technology choice is a factor that influences the business success. Several parameters that need to consider in technology selection i.e., accuracy of technology and raw materials, investment costs, and also success in the other area [8]. In this case the factors and several sub-factors that make up the objectives of alternative media, illustrated in Figure 2. With the development of an alternative hierarchy will make it easier to interpret the objectives to be achieved.

\section{B. Process}

From the hierarchy that has been determined in Figure 2, the paired matrix is determined. The value of each matrix is the result of filling out the questionnaire by management. Table 1 is the result of the calculation of the paired matrix to determine the weights between Price, Technology, and Endurance. Based on the Table 1, it can be seen that, the main criteria that chosen by the management is price, known from its highest weight value (0.43). Nevertheless, the weight value of technology (0.40) is does not much different from the price value. Table 2 was the of pairwise comparison matrix calculations to determinethe weight sub criteria of Price. Table 2 shows that that management chose to allocate funds for the procurement of new goods compared to funds for maintenance. It shows from the weight value of procurement (0.75), compared to the maintenance weight value $(0.25)$.

The results of pairwise comparison matrix calculations to determinethe weight sub criteria of Technology, is shown in 
The $1^{\text {st }}$ International Conference on Business and Engineering Management (IConBEM)

February $1^{\text {st }} 2020$, Institut Teknologi Sepuluh Nopember, Surabaya, Indonesia

Table 1.

Pairwise criteria of main parameters

\begin{tabular}{lllll}
\hline \hline Criteria & Price & Technology & Endurance & Weight \\
\hline Price & 1,00 & 1,42 & 1,86 & 0,43 \\
Technology & 0,70 & 1,00 & 3,04 & 0,40 \\
Endurance & 0,54 & 0,33 & 1,00 & 0,18 \\
\hline \hline
\end{tabular}

Table 2.

Pairwise sub criteria Price

\begin{tabular}{cccc}
\hline \hline Sub Criteria Price & Procurement & Maintenance & Weight \\
\hline Procurement & 1,00 & 1,90 & 0,75 \\
Maintenance & 0,53 & 1,00 & 0,25 \\
\hline \hline
\end{tabular}

Table 3.

Pairwise sub criteria technology

\begin{tabular}{ccccc}
\hline \hline Sub Criteria of technology & Ease & Speed & practicality & Weight \\
\hline Ease & 1,00 & 2,17 & 1,70 & 0,49 \\
Speed & 0,46 & 1,00 & 1,22 & 0,26 \\
Practicality & 0,59 & 0,82 & 1,00 & 0,25 \\
\hline \hline
\end{tabular}

consistency ratio $(\mathrm{CR})=0,020$

Table 4.

Pairwise sub criteria endurance

\begin{tabular}{cccc}
\hline \hline Sub criteria Endurance & Weather & Vandalism & Weight \\
\hline Weather & 1 & 2,53 & 0,72 \\
Vandalism & 0,40 & 1 & 0,28 \\
\hline \hline
\end{tabular}

Table 5.

Pairwise alternative procurement

\begin{tabular}{ccccc}
\hline \hline Alternative procurement & QR Code & RFID & LBS & Weigtht \\
\hline QR Code & 1,00 & 4,67 & 2,83 & 0,63 \\
RFID & 0,21 & 1,00 & 0,49 & 0,13 \\
LBS & 0,35 & 2.04 & 1,00 & 0,24 \\
\hline \hline consistency ratio $(\mathrm{CR})=0,006$ & &
\end{tabular}

consistency ratio $(\mathrm{CR})=0,006$

Table 3. Table 3 told that in the sub criteria technology, ease of use is the most important choice for technology to be easy to use. The number of ease weight value is twice bigger than the other sub citeria (speed and practically), 0.49 compared to 0.26 and 0.25 . The result of pairwise comparison matrix calculations to determine the weight sub criteria of endurance is shown in Table 4. It is noted that that resistance to weather is more important than resistance to vandalism $(0.72$ compared to 0.28 ).

Results of paired matrix calculations to determine the weighting of alternative technologies with procurement is appeared in Table 5 to Table 11. Management agree to choose QR code as the technology to be used in the Purwodadi Botanic Garden, showed from the QR code weight value which is higher than the other two technology which is RFID and LBS. The parameter tested that gives the same results are procurement, maintenance, ease, speed, practically, and vandalism endurance. Those six parameters give the same results that QR codes technology is the chosen. However, for the weather endurance parameters in Table 10, the highest weight score is belonging to LBS technology ( 0.70 compared to 0.11 and 0.18 for LBS technology, RFID, and QR code respectively).

From the several tables above, the global average is calculated to find out the weight of each alternative. In Table 12 shows the total calculations of each alternative for all parameters compared. The result showed that QR Code weight total is the highest among two other technology alternative.
Table 6

Pairwise alternative with maintenance

\begin{tabular}{ccccc}
\hline \hline Alternative Maintenance & QR Code & RFID & LBS & Weight \\
\hline QR Code & 1,00 & 4,83 & 2,23 & 0,60 \\
RFID & 0,21 & 1,00 & 0,37 & 0,12 \\
LBS & 0,45 & 2,70 & 1,00 & 0,29 \\
\hline \hline
\end{tabular}

consistency ratio $(\mathrm{CR})=0,006$

Table 7.

Pairwise alternative with ease

\begin{tabular}{ccccc}
\hline \hline Alternative ease & QR Code & RFID & LBS & Weight \\
\hline QR Code & 1,00 & 3,70 & 3,04 & 0,63 \\
RFID & 0,27 & 1,00 & 1,16 & 0,19 \\
LBS & 0,33 & 0,86 & 1,00 & 0,18 \\
\hline \hline
\end{tabular}

consistency ratio $(\mathrm{CR})=0,016$

Table 8.

Pairwise alternative with speed.

\begin{tabular}{ccccc}
\hline \hline Alternative speed & QR Code & RFID & LBS & Weight \\
\hline QR Code & 1,00 & 3,67 & 3,50 & 0,57 \\
RFID & 0,27 & 1,00 & 1,95 & 0,14 \\
LBS & 0,29 & 0,51 & 1,00 & 0,29 \\
\hline \hline
\end{tabular}

consistency ratio $(\mathrm{CR})=0,070$

Table 9.

Pairwise alternative with practicality.

\begin{tabular}{ccccc}
\hline \hline Alternatif Kepraktisan & QR Code & RFID & LBS & Weight \\
\hline QR Code & 1,00 & 3,00 & 3,00 & 0,61 \\
RFID & 0,33 & 1,00 & 0,50 & 0,19 \\
LBS & 0,33 & 2,00 & 1,00 & 0,20 \\
\hline \hline
\end{tabular}

consistency ratio $(\mathrm{CR})=0,076$

\section{Discussion}

AHP method can be used in the selection of information technology, because information technology is very dynamic, which always carries the latest innovation with several new advantages [9]. One of the studies using the AHP method is the selection of mobile phones based on the technology carried. Based on this research AHP is a structured problem solving technique and can be used as an alternative to making choices [10].

Based on the AHP analysis that used in this research, it appears that management chose the price criteria as the most important criteria compared to two other factors i.e. technology and endurance. Management might choose technology as the most important criteria, but high technology usually has a higher price as well and that might hamper the development of information media innovation in flora tourism. In the price sub-criteria of the calculation results Table 2. The management is more concerned to the procurement than maintenance.

From the three digital technology alternatives offered, QR Codes are the alternatives that have the highest weight in terms of procurement and maintenance that can be seen in Table 5. And Table 6. QR Codes is already applied in many subject area that is museum guide tour, print media industry and education. This technology also declared successful to send information digitally to tourist visitors [7], enrich the content of print media to connect with multimedia content [11], connect students with interesting audiovisual material [12].

\section{CONCLUSION}

Multi-criteria problem solving using the Analytical Hierarchy Process method is very applicable. The challenge 
The $1^{\text {st }}$ International Conference on Business and Engineering Management (IConBEM)

February $1^{\text {st }} 2020$, Institut Teknologi Sepuluh Nopember, Surabaya, Indonesia

Table10.

Pairwise alternative with weather endurance.

\begin{tabular}{ccccc}
\hline \hline Alternative weather & QR Code & RFID & LBS & Weight \\
\hline QR Code & 1,00 & 2,00 & 0,20 & 0,18 \\
RFID & 0,50 & 1,00 & 0,20 & 0,11 \\
LBS & 5,00 & 5,00 & 1,00 & 0,70 \\
\hline \hline
\end{tabular}

consistency ratio $(\mathrm{CR})=0,075$

Table11.

Pairwise alternative with vandalism endurance.

\begin{tabular}{ccccc}
\hline \hline Alternative Vandalism & QR Code & RFID & LBS & Weight \\
\hline QR Code & 1,00 & 2,64 & 1,15 & 0,46 \\
RFID & 0,38 & 1,00 & 1,02 & 0,24 \\
LBS & 0,87 & 0,98 & 1,00 & 0,30 \\
\hline \hline
\end{tabular}

consistency ratio $(\mathrm{CR})=0,076$

in filling out the questionnaire by experts is providing an explanation of each of the factors, criteria, sub-criteria, and alternatives chosen must be explained properly. In filling out the questionnaire it is better to be accompanied to avoid misperceptions.

From the results of the assessment of experts in Purwodadi Botanical Garden management, the following results were obtained. At the chosen position is QR Codes technology with a weight value $(0,56)$, next is an alternative LBS technology with a weight $(0,28)$, and at the end of the management choice is RFID with a weight $(0,16)$. Thus the choice of technology to support flora tourism in Purwodadi botanical gardens is Quick Response Codes technology. From the results of this study can be developed next research on users, whether the technology can be well received or not.

\section{REFERENCES}

[1] Republik Indonesia, Peraturan Presiden No. 93 Tahun 2011, vol. 25, no. 1. 2011, p. 38319.

[2] Kebun Raya Purwodadi, "Laporan Kinerja (LKj) Balai Konservasi Tumbuhan Kebun Raya Purwodadi,” Pasuruan, 2018.

[3] Kebun Raya Purwodadi, "Sejarah Kebun Raya Purwodadi," Penelitian Konservasi Layanan dan Jasa Informasi, 2001. [Online].
Table 12 .

Global weight alternative

\begin{tabular}{ccccc}
\hline \hline \multicolumn{2}{c}{ Global Weigth } & QR Code & RFID & LBS \\
\hline Price & Procurement & 0,18 & 0,04 & 0,07 \\
Price & Maintenance & 0,09 & 0,02 & 0,04 \\
Technology & Ease & 0,12 & 0,04 & 0,04 \\
Technology & Speed & 0,07 & 0,02 & 0,02 \\
Technology & Practicality & 0,06 & 0,02 & 0,02 \\
Endurance & Weather & 0,02 & 0,01 & 0,09 \\
Endurance & Vandalism & 0,02 & 0,01 & 0,02 \\
\multicolumn{2}{r}{ Weight total } & 0,56 & 0,16 & 0,28 \\
\hline \hline
\end{tabular}

Available: http://www.krpurwodadi.lipi.go.id/tentang/sejarah/ [Accessed: 20-Apr-2020].

[4] M. Y. Aryata, "Gedung Informasi Perkebunrayaan, Sarana Diseminasi Iptek LIPI Di Jawa Timur,” 2019. [Online]. Available: http://www.krpurwodadi.lipi.go.id/whatson/detil/?whatson=464. [Accessed: 20-Apr-2020].

[5] C. Legner et al., "Digitalization: Opportunity and Challenge for the Business and Information Systems Engineering Community," Bus. Inf. Syst. Eng., vol. 59, 2017, doi: 10.1007/s12599-017-0484-2.

[6] D. McMenemy and A. Poulter, Delivering digital services : a handbook for public libraries and learning centres. London: Facet, 2005.

[7] M. P Erez-Sanagustín, D. Parra, R. Verdugo, G. García-Galleguillos, and M. Nussbaum, "Using QR codes to increase user engagement in museum-like spaces," 2016, doi: 10.1016/j.chb.2016.02.012.

[8] J. Kasmir, Studi Kelayakan Bisnis. Jakarta: Prenada Media, 2009.

[9] D. Fablius, "Rancang Bangun Sistem Penentuan Keputusan untuk Distribusi Penyedian Kontainer dengan Multi Kriteria Secara Dinamis," 2017.

[10] A. Adhi, "Pengambilan Keputusan Pemilihan Handphone Terbaik Dengan Anaylytical Hierarchy Process (AHP)," Din. Tek., vol. IV, no. No. 2 Juli 2010, pp. 24-33, 2010.

[11] T. H. Mihardja, "QR Code Kompas Perkaya Konten bagi Pembaca Halaman all - Kompas.com," kompas.com, 15-Jun-2009. [Online]. Available:

https://tekno.kompas.com/read/2009/06/15/0850503/QRCode.Kom pas.Perkaya Konten.bagi.Pembaca?page=all. [Accessed: 20-Apr2020].

[12] H. C. Lai, C. Y. Chang, L. Wen-Shiane, Y. L. Fan, and Y. T. Wu, "The implementation of mobile learning in outdoor education: Application of QR codes," Br. J. Educ. Technol., vol. 44, no. 2, pp. 57-62, 2013, doi: 10.1111/j.1467-8535.2012.01343.x. 